Egyptian Journal of Aquatic Biology \& Fisheries

Zoology Department, Faculty of Science,

Ain Shams University, Cairo, Egypt.

ISSN $1110-6131$

Vol. 23(5): 357 - 366 (2019)

www.ejabf.journals.ekb.eg

\title{
Length-Weight Relationships of Thirteen Species of Parrotfish (Family Scaridae) inhabiting the Egyptian coasts of the Red Sea.
}

\author{
Amal M. Amin*, Azza A. El-Ganainy and Manal M. Sabrah \\ National Institute of Oceanography and Fisheries, Suez, Egypt. \\ *Corresponding Author: aminamal30@yahoo.com
}

\section{ARTICLE INFO \\ Article History: \\ Received: Sept. 8, 2019 \\ Accepted: Nov. 27, 2019 \\ Online: Dec. 2019}

Keywords:

Red Sea

Scaridae

Chlorurus geuozonatus

Calotomus viridescens

Parrotfish

growth type

\begin{abstract}
Length-weight data of population are basic parameters for any monitoring study of fishes since it provides important information about the structure of the populations. Also, it is important for fish stock assessment essential for estimating growth rates, age structure, calculate the standing stocks biomass, condition indices and several other aspects of fish population dynamics. Therefore, we investigated the length-weight relationships of 13 parrotfish species (Family Scaridae) collected seasonally from the Egyptian Red Sea coast during 2014/2016. The" b "values of the length-weight relationships ranged from 2.17 to 3.88 with a mean value of $2.729 \pm 0.0788$ (S.E.) for the studied species. Chlorurus geuozonatus showed a positive allometric growth while Calotomus viridescens; Cetoscarus bicolor; Chlorurus sordidus; Chlorurus gibbus; Hipposcarus harid; Scarus frenatus; Scarus ferrugineus; Scarus fuscopurpuerus; Scarus ghobban; scarus niger and Scarus psittacus were show a negative allometric growth. Isometric growth was represented by two species Hipposcarus harid and Scarus colon. $98 \%$ of the studied species had " $\mathrm{R}^{2}$ " values higher than 0.90 , which indicated the increase in length will contribute with increase in weight. These results are useful references for the management plan.
\end{abstract}

\section{INTRODUCTION}

More than 1270 species of fishes are known to occur in the Red Sea (Khalaf, et al., 1996). The majority of these inhabit coral reefs where they constitute a dominant component of the fish fauna. There are marked differences among the different regions of the Red Sea in fish species richness, assemblage compositions and species' abundance (Sheppard et al., 1992). Family Scaridae, a group of fish's characteristic of coral reefs. Although there are relatively few species about 80 within 10 genera (Bellwood, 1994), they are a dominant group in terms of numbers and biomass in shallow reef environments (Russ 1984 and Choat \& Bellwood 1991).

Every animal in its life show growth both in length and in weight. Studies of the Length-Weight Relationship of fishes were performed since the late 19th century and are an important tool to describe several biological aspects (Froese, 2006). The LWR allows to estimate fish weight based on the length and vice versa, analyze the growth pattern by the allometric coefficient of the analyzed species, and obtain the body conditions of the sampled fish specimens (i.e. fat storage or gonadal development, etc.) (Froese, 2006). Additionally, the knowledge from LWR is essential to assess fish stocks, fisheries, and environmental monitoring programs (Giarrizzo et al. 2015). 
According to (Riedel et al. 2007) the relationship of the growth of one part of an organism to that in another part is called allometry. Fish can attain either isometric growth, is associated with no change of body shape as an organism grows. Negative allometric growth implies the fish becomes more slender as it increases in weight. While positive allometric growth indicates the fish becomes relatively stouter or deeper bodied as it increases in length.

Freitas et al., (2014) showed that depending on the season, availability of food, population, sex, environmental conditions or physiology the growth pattern (b) within the same species was changeable.

Ecoutin et al., (2003) revealed that Fisheries management and research often need the use of biometric relationships to transform data collected in the field into suitable indices. The LWR can be used as a character for the differentiation of taxonomic units and the relationship changes with the various developmental events in life such as metamorphosis growth, and the onset of maturity (Thomas et al. 2003). Besides this, LWR can also be used in setting yield equations for estimating the number of fish landed and comparing the population in space and time (Singh et al. 2011).

Due to the importance of length-weight relationship in fishery assessments, this study aimed to reports the LWR of the thirteen important parrotfish species caught from the Egyptian coast of the Red Sea.

\section{MATERIALS AND METHODS}

\section{Study area:}

The Red Sea is a long, narrow body of water separating north-east Africa from the Arabian Peninsula. The Red Sea is divided into 2 main sectors. The first sector starts from Taba on the border with Israel to Sharm El-Sheikh on the Sinai Peninsula. The samples obtained from the second part passes from north Hurghada south to the Shalateen. It is an area of great physical beauty with different ecosystems and high biological diversity (Fig. 1).

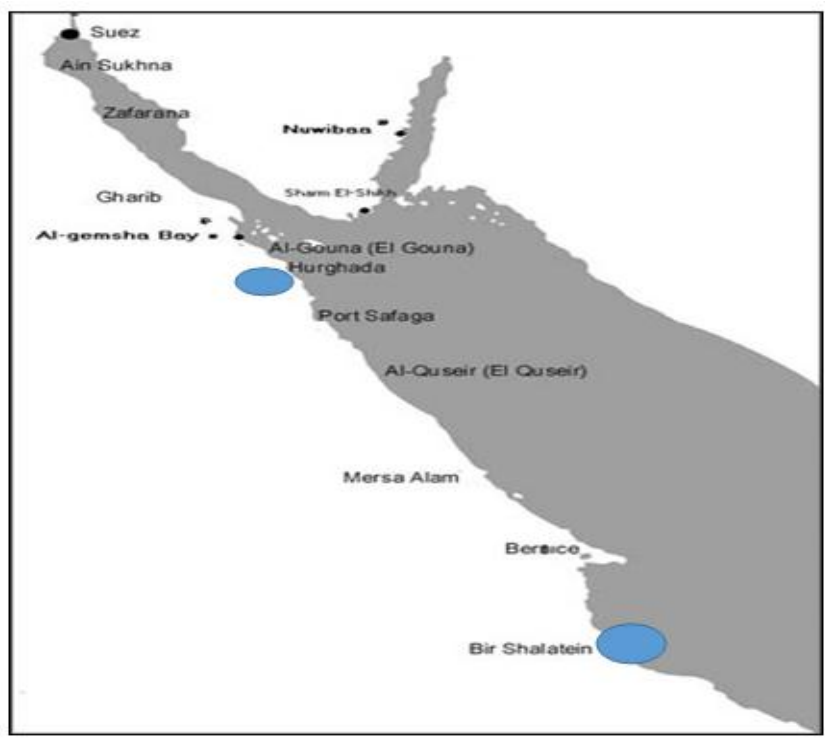

Fig. 1: Egyptian Red Sea coasts from Hurghada to Shalateen recognize the sampling area. 
About 513 samples of parrotfish constituting thirteen species, belonging to five genera collected seasonally from 2014 to 2016. The length-weight relationship was analyzed by measuring the total length $(\mathrm{cm})$ and total weight $(\mathrm{g})$ for each individual. Parameters of the length-weight relationship of identified fish species were estimated using the equation: $\mathrm{W}=\mathrm{aL}^{\mathrm{b}}$ (Rickter, 1973)

Where, $\mathrm{W}=$ total weight of fish $(\mathrm{g}) ; \mathrm{L}=$ total length of fish $(\mathrm{cm}), \mathrm{a}=\mathrm{y}$-intercept or the initial growth coefficient and $b=$ the slope or the growth coefficient or relative growth rate of fish.

The values of constants "a", 'b " and 95\% confidence limits for (anti-log a) and (b) were estimated after logarithmic transformation of Eq. (1) using least square linear regression (Zar, 1984) to give: $\log W=\log a+b \log L$

The degree of association between the variables and the goodness of fit of the regression model is indicated by the ' $R$ ' ' value in the output.

Furthermore, the $b$-value for each species was tested by (t-test) to verify if it was significantly different from isometric growth $(b=3)$. While a statistically significant difference of $b$ from 3 suggests an allometric growth either positive or negative $(\mathrm{P}<0.05)$, an isometric growth is given when $\mathrm{b}$ is not statistically different from $3(\mathrm{P}>0.05)$ (Yilmaz et al. 2012).

\section{RESULTS AND DISCUSSION}

All the Parrotfish species were identified as 13 species belonging to five genera. The first Genus was Hipposcarus represented by (Hipposcarus harid). While the second Genus was Scarus included seven species Scarus ghobban (Forsskål, 1775; Scarus psittacus Forsskål, 1775; Scarus colon; Scarus niger Forsskål, 1775; Scarus frenatus Lacepède, 1802; Scarus ferruginous and scarus fuscopurpuerus. The third Genus was Chlorurus which has three species (Chlorurus genazonatus; Chlorurus gibbus and Chlorurus sordidus (Forsskål, 1775). The fourth Genus was reported as Cetoscarus and represented by Cetoscarus bicolor. Finally, Genus Calotomus represented by Calotomus viridescens.

\section{Parrotfish species composition}

During the study period, the specimens comprising 13 parrotfishes species. The most dominant species was Hipposcarus harid included the highest percent of the total sample $(34.89 \%)$, followed by Chlorurus sordidus $(22.61 \%)$, and scarus fuscopurpuerus was recorded by (14.42\%). whereas Calotomus viridescens and Scarus ghobban were contributed the same percent $(4.68 \%)$, followed by Scarus collon (4.48\%), and Scarus ferrugineus (3.90\%). Scarus niger and Scarus frenatus were recorded by $(3.51 \%)$ and $(3.31 \%)$ respectivily. Scarus psittacus, chlorurus geuozonatus and Cetoscarus bicolor were represented by small percentages, $(1.17 \%$, $0.78 \%, 0.58 \%$ ) respectively ( Fig. 2 ). 


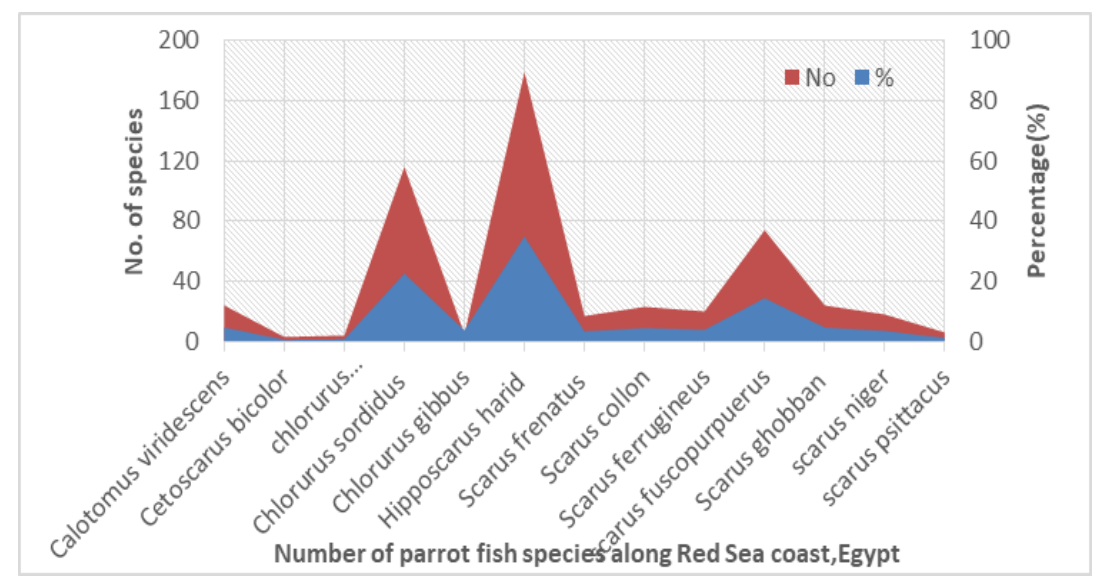

Fig. 2: Parrotfish species composition distributed along the Egyptian Red Sea coast during 2014/2016.

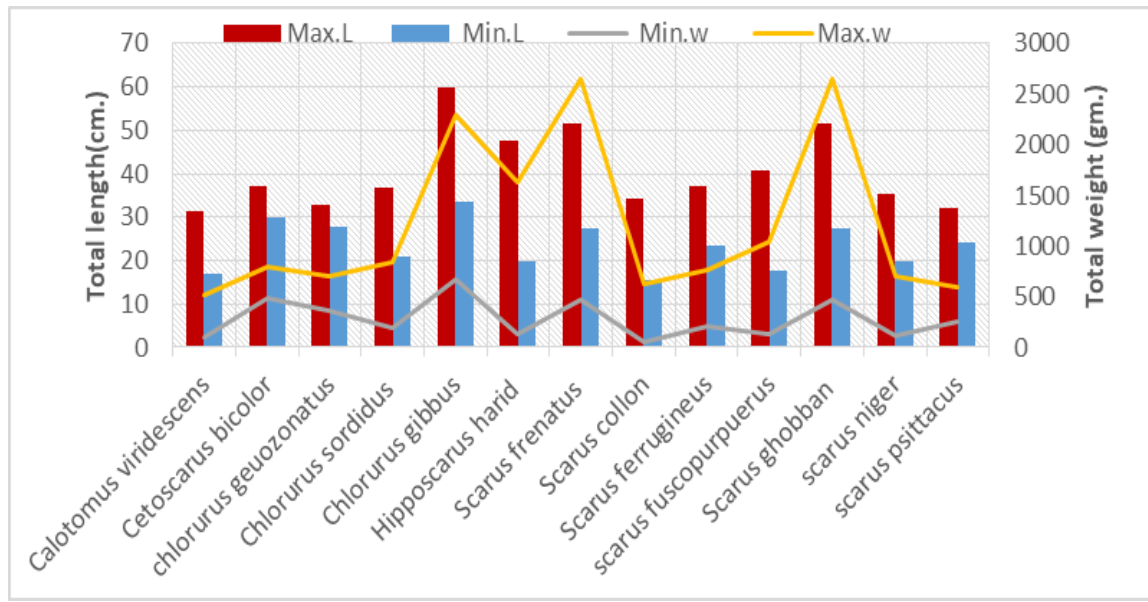

Fig. 3: Minimum and maximum total length (cm.) and total weight (gm.) for Parrotfish species collected from the Egyptian Red Sea coast during 2014/2016.

\section{Length-weight relationship}

Parrotfishes, family Scaridae are important agents in marine bioerosion. The length-weight relationship of thirteen species of parrotfishes was estimated. The total length ranged from the smallest one $15.5 \mathrm{~cm}$ in Scarus colon to $60 \mathrm{~cm}$ the largest length recorded in Chlorurus gibbus. While the smallest total weight recorded was 94.2gm in Calotomus viridescens and the largest one was recorded in Scarus frenatus (2654.7gm.).The maximum and minimum length and weight for all species are shown in Fig. (3). The descriptive statistics of the length and weight of thirteen parrotfish's species was estimated as shown in Table (1).

The length-weight relationships for nine parrotfish species are shown in Fig. 4 (from Fig. A to Fig. I). Table (2) clarifies the corresponding values of intercept "a", slope "b", "R ${ }^{2 "}$, coefficient of determination; $\mathrm{CI}$ : confidence interval, standard error "SE of b", type of growth (A+, allometric positive; A-, allometric negative and I, isometric) and the significant differences from 3. It is clear from Table (2) that each species has specific length-weight parameters. The parameter "a" is a scaling coefficient for the weight at length of the fish species. While the parameter " $b$ " is a shape parameter for the body form of the fish species. 
Table 1: Descriptive statistics of the length and weight of thirteen parrotfish species from the Egyptian Red Sea coast.

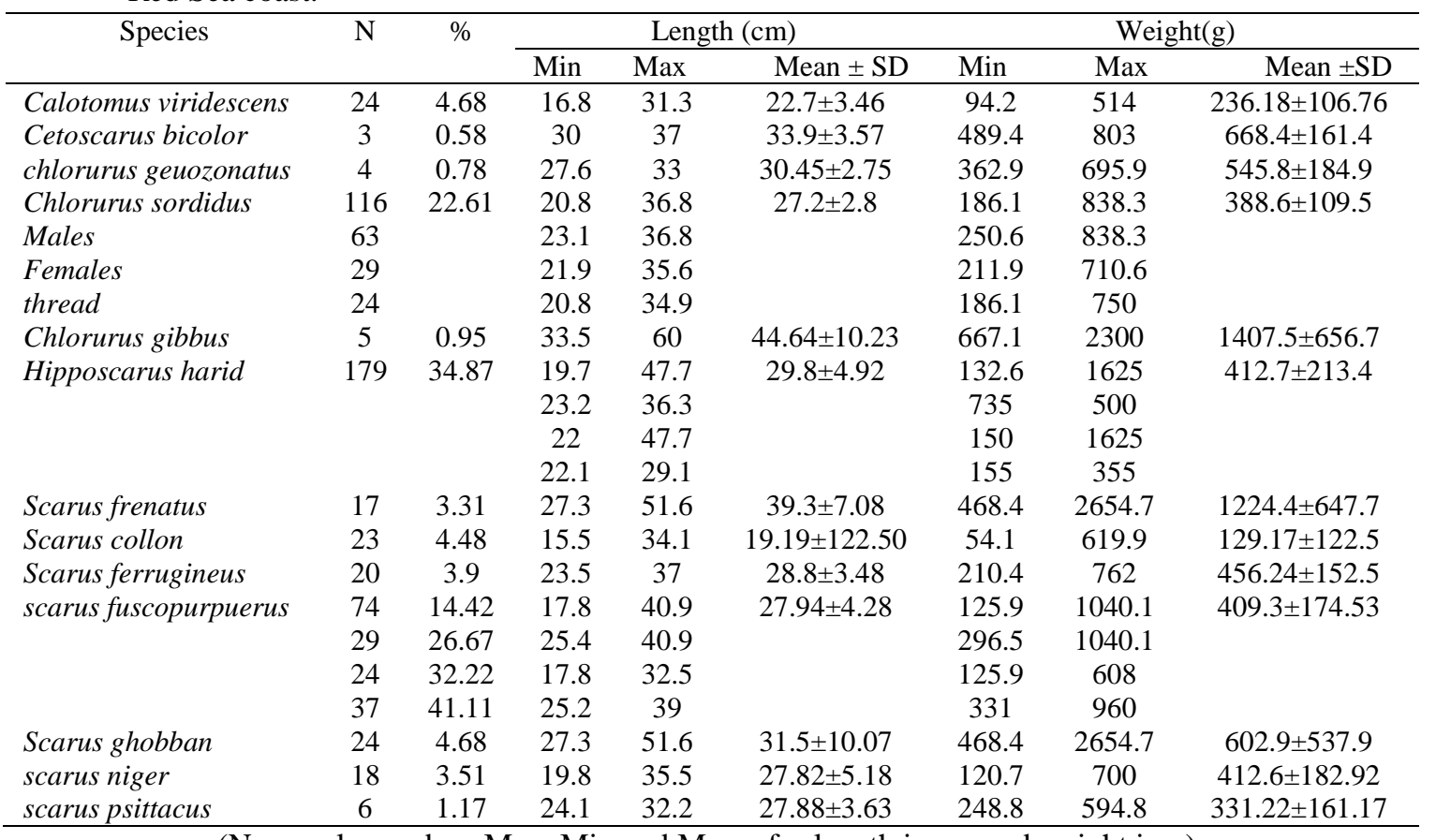

(N, sample number; Max, Min and Mean, for length in $\mathrm{cm}$ and weight in $\mathrm{g}$ ).

The highest value of parameter "b" (Table 2) was recorded in Chlorurus geuozonatus (3.88) and the lowest one was observed as 2.17 for Chlorurus gibbus. The mean" $b^{\prime \prime}$ value was $2.729( \pm 0.370 \mathrm{SD})$ and the median was 2.745 for all species. It is also clear that most of parrotfish are different from 3, which are reflecting the tendency to be negative allometric growth $\left(\mathrm{A}^{--}\right)$. The fish in which the value of " $\mathrm{b}$ " ranges between 2.5 to 4 live in good conditions (Le Cren, 1951). These results indicated that the environmental conditions in the Egyptian Red Sea are suitable for parrotfish's growth.

In terms of growth type, Calotomus viridescens; Cetoscarus bicolor; Chlorurus sordidus; Chlorurus gibbus; Hipposcarus harid; Scarus frenatus; Scarus ferrugineus; scarus fuscopurpuerus; Scarus ghobban; scarus niger, and scarus psittacus revealed negative allometric growth $(b<3)$. One species chlorurus geuozonatus recorded positive allometric growth $(b>3)$. Isometric growth was observed for Hipposcarus harid and Scarus colon. All regressions were highly significant $(\mathrm{p}<0.001)$ and the coefficient $R^{2}$ values ranged from 0.42 for Scarus psittacus to 0.98 for Hipposcarus harid.

Several authors have reported each allometric and isometric growth pattern for different parrotfish species from various water bodies. The negative allometric growth in S. psittacus (2.90) was reported by (Choat et al, 1996) in Lizard Island, Australia; they also reported the isometric growth for $S$. frenatus $(b=3.06) ; S$. niger (3.09) and the positive allometric growth was noticed in S. rivulatus (3.14) and S. schlegeli (3.12). Veeramani, et al (2010) in the Southeast coast of India noticed that b value was 2.54 for S. ghobban; Mehanna, et al 2014 from Hurghada, Red Sea, Egypt concluded the " b" value 2.93 for $H$. harid while 3.02 for $C$. sordidus .In the other hand Kamikawa et al . (2015) from Guam, shown negative allometric growth for both Cetoscarus bicolor and Scarus ghobban $\mathrm{b}=2.92$ while and reported isometric growth 3.04; 3.06 for Chlorurus sordidus and Scarus psittacus respectively. El-Sayed et al. (2011) from the eastern coast of the Red Sea, at Jeddah, Saudi Arabia estimated the 
values of the allometric index "b" were ranged from 2.94 to 3.09 for Hipposcarus harid; Scarus ferrugineus and Chlorurus sordidus. "b" value in fishes can be affected by several factors including habitat, fishing season, degree of stomach fullness, gonad maturity, sex and preservation techniques (Wootton, 1998).

The present work showed that $98 \%$ of the study species had" $\mathrm{R}^{2 "}$ values higher than 0.90 , indicates a high correlation between the length and weight and proved to be highly significant. While $1 \%$ had $\mathrm{R}^{2}$ values ranged from 0.80 to 0.86 as in (Chlorurus sordidus) and (Scarus psittacus) due to the few samples in this species. All the statistical analyses were considered at a significance level of $5 \%(\mathrm{p}<0.05)$. This was in agreement with previous studies on different parrotfish species from various areas. (Dhakal and Subba, 2003) revealed that if the value of $\left(\mathrm{R}^{2}\right)$ is found to be higher than 0.5 , it shows that the LWR is positively correlated and vice versa. (Goel et al. 2011) indicated that if $\left(\mathrm{R}^{2}>0.9\right)$ and the weight increases in length, this indicated that the fish maintains its shape throughout its life.

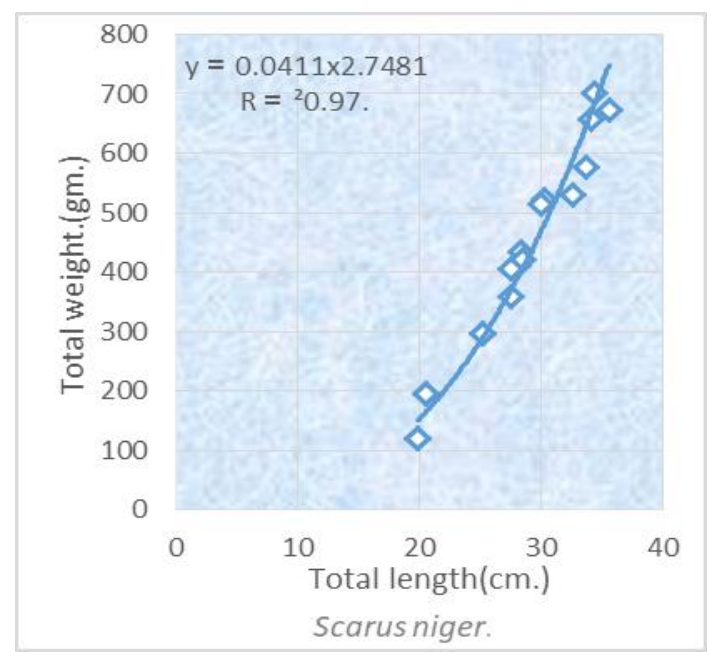

Fig. (A)

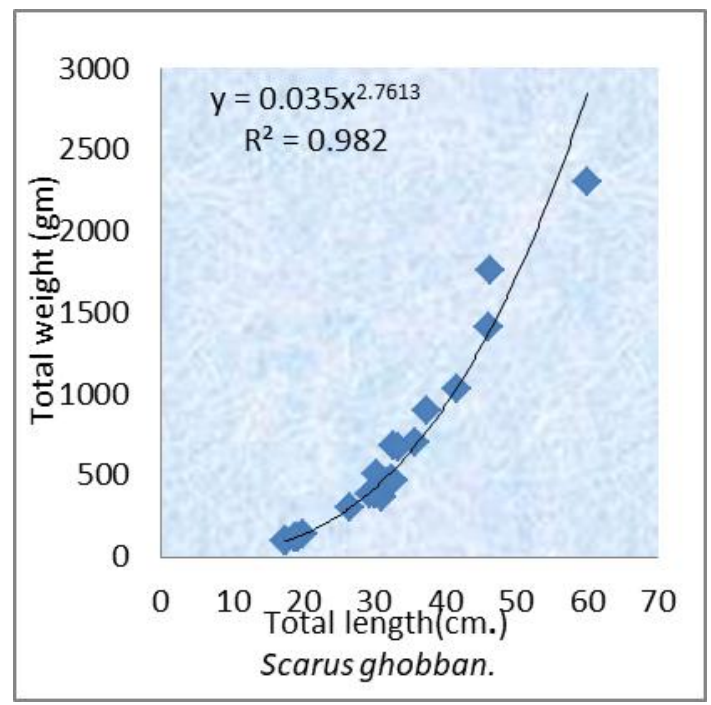

Fig. (C)

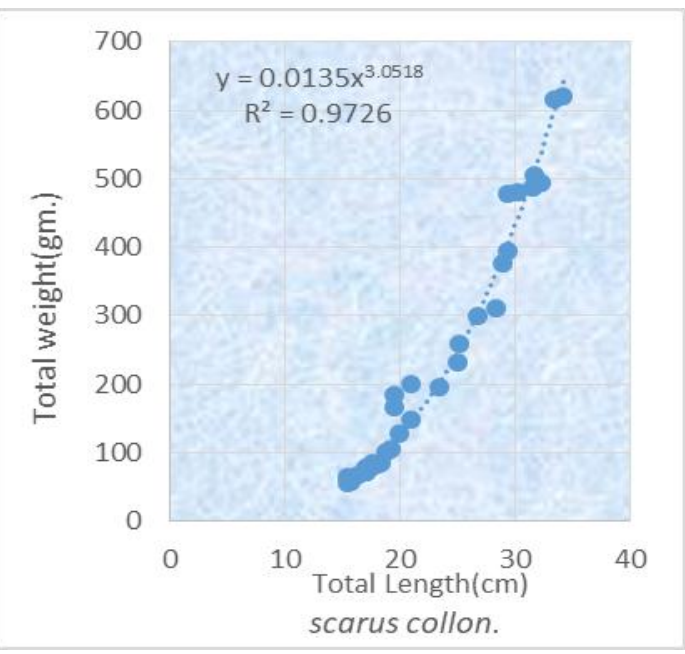

Fig. (B)

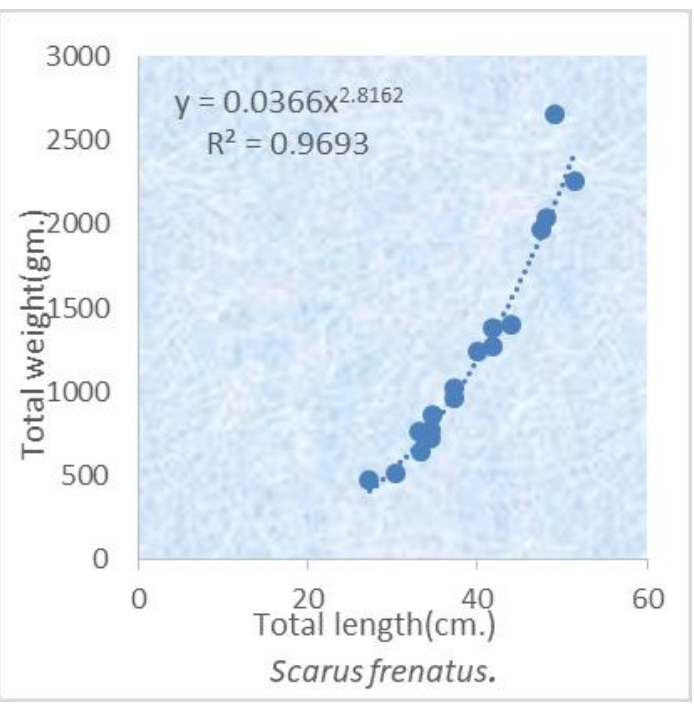

Fig. (D) 


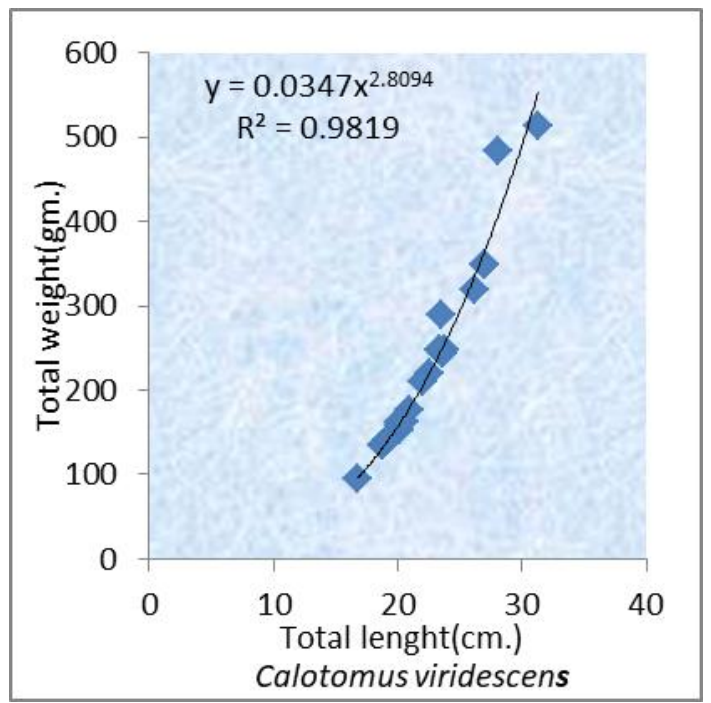

Fig. (E)

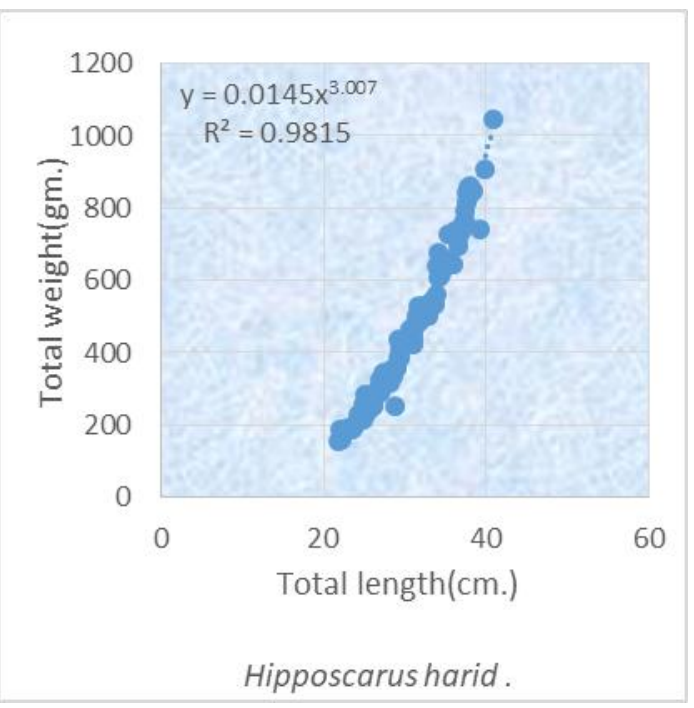

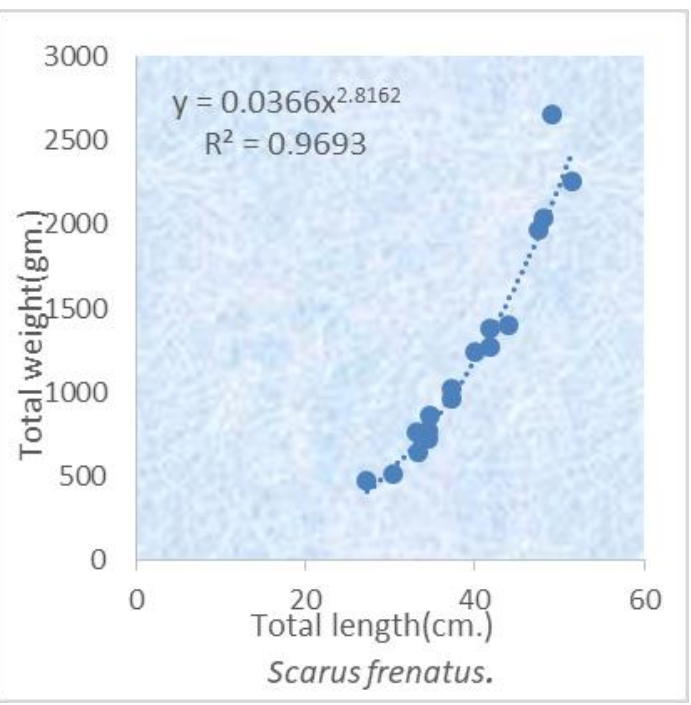

Fig. (F)

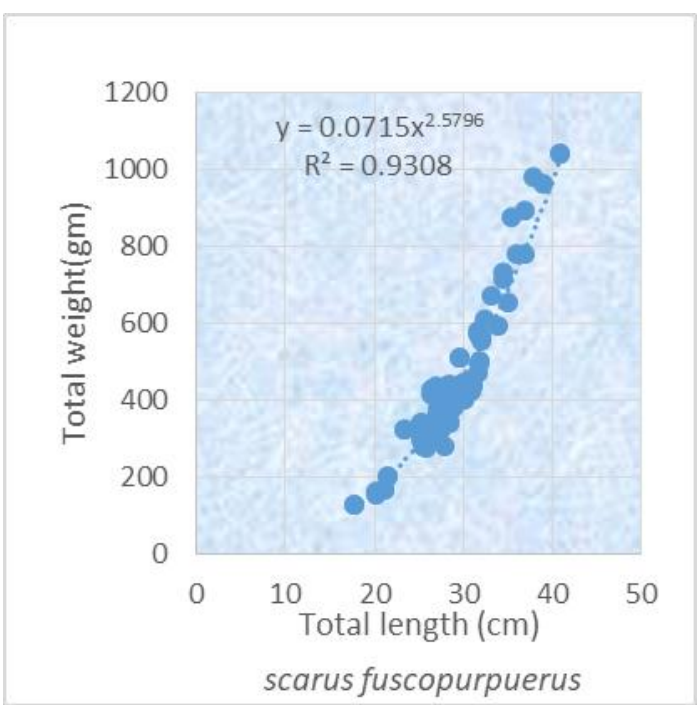

Fig. (G)

Fig. (H)

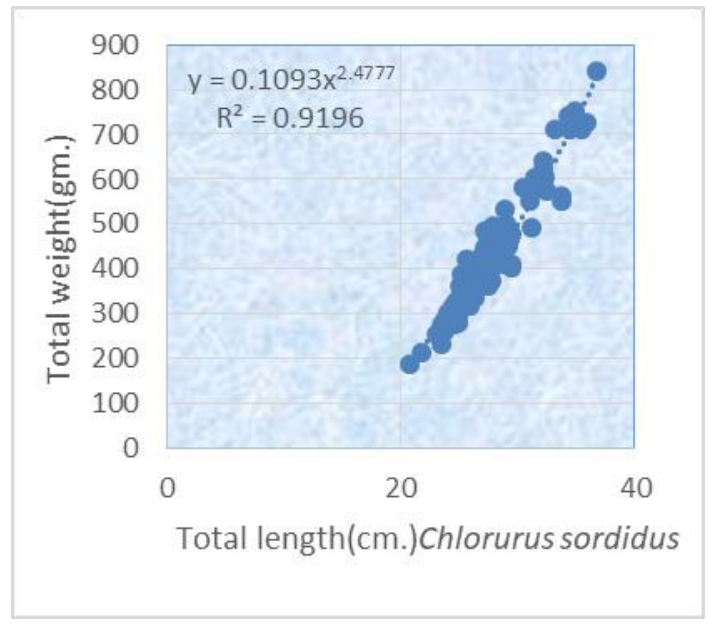

Fig. (I)

Fig. 4: (From Fig. (A) to Fig. (I) ) The length-weight relationship for different Parrotfish species from the Egyptian Red Sea coast during 2014/2016. 
Table 2: Length-weight relationship Parameters of thirteen parrotfish species in the Egyptian Red Sea coast.

\begin{tabular}{|c|c|c|c|c|c|c|c|c|}
\hline Species & $a$ & $b$ & $\begin{array}{l}S E \\
\text { (b) }\end{array}$ & $C L(b)$ & $r 2$ & $\boldsymbol{P}$ & $\begin{array}{l}\text { t-test } \\
\text { sig }\end{array}$ & $\begin{array}{l}\text { Growth } \\
\text { behavior }\end{array}$ \\
\hline $\begin{array}{l}\text { Calotomus } \\
\text { viridescens }\end{array}$ & 0.035 & 2.81 & 0.081 & $2.64-2.98$ & 0.98 & & & A- \\
\hline Cetoscarus bicolor & 0.14 & 2.40 & 0.170 & & 0.99 & & & A- \\
\hline $\begin{array}{l}\text { chlorurus } \\
\text { geuozonatus }\end{array}$ & 0.001 & 3.88 & 0.09 & $3.51-4.24$ & 0.99 & 0.000 & & $\mathrm{~A}^{+}$ \\
\hline Chlorurus sordidus & 0.109 & 2.48 & 0.07 & $2.34-2.61$ & 0.92 & $<0.05$ & $*$ & A- \\
\hline Chlorurus gibbus & 0.289 & 2.17 & 0.29 & $1.25-3.09$ & 0.95 & 0.004 & $*$ & A- \\
\hline Hipposcarus harid & 0.015 & 3.01 & & & 0.98 & & $*$ & I \\
\hline Scarus frenatus & 0.129 & 2.816 & 0.129 & 2.54-3.09 & 0.97 & & & A- \\
\hline Scarus collon & 0.014 & 3.01 & 0.10 & $2.80-3.22$ & 0.98 & 0.005 & $*$ & I \\
\hline Scarus ferrugineus & 0.028 & 2.88 & 0.16 & $2.53-3.22$ & 0.94 & & $*$ & A- \\
\hline $\begin{array}{l}\text { scarus } \\
\text { fuscopurpuerus }\end{array}$ & 0.072 & 2.58 & 0.075 & $2.43-2.73$ & 0.93 & & $*$ & $\begin{array}{l}\text { A- } \\
\text { A- }\end{array}$ \\
\hline Scarus ghobban & 0.035 & 2.77 & 0.08 & $2.60-2.93$ & 0.98 & & $*$ & A- \\
\hline scarus niger & 0.0411 & 2.75 & 0.15 & $2.44-3.06$ & 0.98 & $<0.05$ & $*$ & A- \\
\hline scarus psittacus & 0.20 & 2.212 & 1.29 & 2.21 & 0.42 & 0.16 & & A- \\
\hline
\end{tabular}

(a, intercept of the relationship; $b$, the slope of the relationship; $r^{2}$, coefficient of determination; CI: confidence interval standard error of $\mathrm{b}$; $\mathrm{A}+$, allometric positive; A-, allometric negative; I, isometric).* significant differences from $3(\mathrm{P}<0.05)$.

\section{CONCLUSION}

This study provides the first baseline information on the length-weight relationship of thirteen parrotfishes species collected from the Egyptian Red Sea coast. Almost LWRs showed a negative allometric growth which might be attributed to environmental conditions or linked to morphological characteristics specific to each species. These results are useful references for fishery biologists in a management plan. 


\section{REFERENCES}

Bellwood, D. R. (1994). A phylogenetic study of the parrotfishes, family Scaridae (Pisces: Labroidei), with a revision of genera. Rec. Aust. Mus., (20)1-86.

Choat, J. H. and Bellwood, D. R. (1991). Reef fishes: their history and evolution. In The ecology of fishes on coral reefs (pp. 39-66). Academic Press.

Choat, J, H.; Axe, L.M. and Lou, D.C. (1996). Growth and Longevity in Fishes of the Family Scaridae. Marine Ecology Program Seri,145: 33 - 41.

Dhakal, A. and Subba, B.R. (2003). Length-Weight Relationship of Lepidocephalichthys guntea of Pathri Khola, Morang District. Our Nature, 1: 53-57.

Ecoutin, J. M.; Albaret, J. J. and Trape, S. (2005). Length-weight relationships for fish populations of a relatively undisturbed tropical estuary: The Gambia. Fisheries Research, 72(2-3): 347-351.

El-Sayed, A. T.; Osman, A. M.; Abdel-Aziz, S. H. and Bawazeer, F. A. (2011). Growth and longevity of the protogynous parrotfish, Hipposcarus harid, Scarus ferrugineus and Chlorurus sordidus (Teleostei, Scaridae), off the eastern coast of the Red Sea. Journal of Applied Ichthyology, 27(3): 840-846.

Freitas, T. M. S.; Prudente, B. S.; Fontoura, N. F. and Montag, L. F. A. (2014). Length-weight relationships of dominant fish species from $C$ axiuanã National Forest, Eastern Amazon, Brazil. Journal of Applied Ichthyology, 30(5): 10811083.

Froese, R. (2006). Cube law, condition factor, and weight-length relationships: history, meta-analysis, and recommendations. Journal of applied Ichthyology, 22(4): 241-253.

Giarrizzo, T.; de Sena Oliveira, R. R..; Costa Andrade, M.; Pedrosa Gonçalves, A.; Barbosa, T. A. P.; Martins, A. R. and Fogaça de Assis Montag, L. (2015). Length-weight and length-length relationships for 135 fish species from the Xingu River (Amazon Basin, Brazil). Journal of Applied Ichthyology, 31(2): 415-424.

Goel, C.; Barat, A.and Pande V. (2011). Length-Weight Relationship of Snow Trout Schizothorax richardsonii) Based on Linear and Nonlinear Models from Hill Stream of Uttarakhand, India. World Journal of Fish and Marine Sciences, 3: 485-488.

Kamikawa, K. T.; Cruz, E.; Essington, T. E.; Hospital, J.; Brodziak, J. K. T.and Branch, T. A. (2015). Length-weight relationships for 85 fish species from Guam. Journal of applied ichthyology, 31(6): 1171-1174.

Khalaf, M. A.; Disi, A. M. and Krupp, F. (1996). Four new records of fishes from the Red Sea. Fauna of Saudi Arabia, 15: 402-406.

Le Cren, E.D. (1951). The length-weight relationship and seasonal cycle in gonad weight and condition in the Perch (Perca fluviatilis). J. Anim. Ecol., 20: 201219.

Mehanna, S. F.; Abu-Elregal, M.and Abdel-Maksoud, Y. A. (2014). Age and Growth Based on the Scale Readings of the Two Scarid Species Hipposcarus harid and Chlorurus sordidus from Hurgada Fishing Area, Red Sea, Egypt. International Journal of Marine Science, 4.

Rickter, W. E. (1973). Linear regression in fisheries research J. fish. Res. Board can., 30: $409-434$ 
Riedel, R.; Caskey, L. M., and Hurlbert, S. H. (2007). Length-weight relations and growth rates of dominant fishes of the Salton Sea: implications for predation by fish-eating birds. Lake and Reservoir Management, 23:528-535.

Russ, G. R. (1984). Distribution and abundance of herbivorous grazing fishes in the central Great Barrier Reef. II. Patterns of zonation of mid-shelf and outer shelf reefs. Marine Ecology Progress Series, 20: 35-44.

Sheppard, C. R.; Price, A. R. G. and C. M. Roberts. (1992). Marine ecology of the Arabian region: Patterns and Processes in extreme tropical environments. P. 359. Academic Press, London

Singh, N. O.; Sarma, D.and Singh, N. G. (2011). Length-weight relationship of Tor putitora (Hamilton) from Kosi River Uttarakhand considering different stages of its lifespan. Indian Journal of Fisheries, 58(1): 35-38.

Thomas, J.; Venu; S.and Kurup, B. M. (2003). Length-weight relationship of some deep-sea fish inhabiting the continental slope beyond $250 \mathrm{~m}$ depth along the West Coast of India. NAGA, WorldFish Center Quarterly, 26(2): 17-21.

Veeramani, T.; Ravi, V.; Kesavan, K.and Balasubramanian, T. (2010). Length-weight relationship of Parrot fish Scarus ghobban, Forsskal 1775 from Nagapattinam, South East Coast of India. Advances in Biological Research, 4(3), 182-184.

Wootton, R. J. (1998). Ecology of Teleost Fishes, Kluwer Academic Publishers. Dordrecht, The Netherlands.

Yılmaz, S.; Yazıcıoğlu, O.; Erbaşaran, M.; Esen, S.; Zengin, M.and Polat, N. (2012). Length-weight relationship and relative condition factor of white bream, Blicca bjoerkna (L., 1758), from Lake Ladik, Turkey. Journal of Black Sea/ Mediterranean Environment, 18(3): 380-387.

Zar, J. H. (1984). Biostatistical Analysis. Prentice Hall, New Jersey, 718pp. 